\title{
Gamified lessons support molecular genetics education of first year biology students during COVID-19 lockdown
}

\author{
Nicholas M. Andronicos, Terry J. Barnett, Raphael Roberts, Siew Chong, Lea \\ Labeur, Sinead M. Henderson and Adrienne Burns
}

University of New England

\begin{abstract}
This study compared the associated impact of gamified molecular genetics lessons on undergraduate student grades for pre-COVID-19 blended delivery and COVID-19 online only delivery of a first-year biology course. When the molecular genetics gamified lessons were used by on- and off-campus students to support their learning, most students had successful learning outcomes in either blended or online only learning environments. In contrast, students who chose not to use these lessons had significantly greater failure rates for both the molecular biology and the genetics short answer questions in the final invigilated exams. Importantly, there was noticeable gamified lesson fatigue observed by both on- and off-campus students and therefore when incorporating gamified lessons into courses, curriculum design needs to be carefully considered. In conclusion, the use of gamified lessons was associated with significantly reduced student failure rates for molecular genetics concepts studied in a university foundational biology course.
\end{abstract}

Keywords: biology, COVID-19, gamification, e-learning, blended, online, quantitative

\section{Introduction}

The learning success of undergraduate students studying STEM at university is usually dependent on didactic lectures as well as student laboratory experiences. In 2020, this was challenged with the advent of COVID-19 government-imposed travel and social gathering restrictions, forcing most Australian universities to deliver STEM courses in an online only environment (Crawford et al. 2020; Burns et al. 2021). This rapid transition to a fully online teaching environment required using e-learning technologies to deliver traditional STEM lessons asynchronously to students (Burns et al. 2021). The benefits of asynchronous delivery through e-learning resources have been shown to better support cognitive participation, improve reflective participation as well as deep learning, because students have more time to consider concepts (Garrison, 2016).

The structure/function of DNA (molecular biology) and Mendelian genetic inheritance are important, fundamental, concepts for undergraduate students to comprehend in biological science degrees (Cobb, 2018; Redfield, 2012). These conceptual topics are usually introduced to students together as molecular genetics in first year general biology courses at university (Cheesman et al., 2007). The order in which these topics are taught does not affect student learning success (Deutch, 2018). Didactic lectures and laboratory sessions are generally used to teach molecular genetics (Sheely, 2006; White, 2006). Recently, multimedia resources and auxiliary teaching methods have been used to augment these traditional teaching methods (Pelletreau et al., 2016; Liu \& Taylor, 2013; Marshall, 2017; Mclean \& Schuma, 2016; Yung and Primm, 2015; Hall et.al., 2014; DeBruyn, 2012; Altiparmak \& Nakiboglutezer, 2009) and laboratory sessions (White \& Bolker, 2008; cgslab.com; StarGenetics; DrosophiLab, FlyLab JS). Thus, gamified lessons were developed and deployed as the centrepiece resource to teach molecular genetics in blended and online only learning environments.

Gamification is the use of game design principles and mechanics to develop lessons that enhance student learning (Kapp et al., 2013; Loganathan, et al. 2019; Kalogiannakis et al., 2021). Game design principles such as visible status, freedom of choice, and freedom to fail with rapid feedback promote effective learning (Dicheva et al., 2015) and encourage student engagement in a low-risk environment (Bevins \& Howard, 2018; Al-Azawi, et al., 2016), which improves the academic results of students (Bai et al., 2020). Therefore, it was hypothesized that the provision of students with a series of online, gamified molecular genetics lessons exclusively via an online learning environment would facilitate their learning outcomes comparable to students who studied molecular genetics using a blended learning approach consisting of face-to-face teaching and online lessons. Hence, the aims of this study were to: 
1. Develop and deploy gamified lessons, designed to teach students foundational molecular genetics concepts in blended and online only learning environments.

2. Determine if the summative grades of students studying molecular genetics in a blended learning environment were comparable to students studying via an online only learning environment.

\section{Methods}

This study was approved (HE21-079) by the University of New England Human Research Ethics Committee.

\section{Design and deployment of the molecular genetics gamified lessons}

The gamified molecular biology interactive lesson: DNA and Protein Synthesis was built using Blender3D (Blender Foundation, USA), Tumult Hype (Tumult Inc, USA) and Adobe Captivate 2019 (Adobe, USA) as a HTML5 resource. Similarly, three gamified online genetics lessons (Meiosis and the Law of Segregation; Independent Assortment; and Pedigree Analysis) were also developed using Adobe Captivate. All lessons had a branched learning design that contained multiple learning modules (Table 1). These lessons included elements

Table 1. Gamified lesson design and learning interactions included in the molecular genetics' lessons.

\begin{tabular}{|c|c|c|c|c|}
\hline Game Design Features & $\begin{array}{l}\text { DNA \& Protein } \\
\text { Synthesis lesson }\end{array}$ & $\begin{array}{c}\text { Segregation \& } \\
\text { Meiosis Lesson }\end{array}$ & $\begin{array}{c}\text { Independent } \\
\text { Assortment Lesson }\end{array}$ & $\begin{array}{c}\text { Pedigree Analysis } \\
\text { Lesson }\end{array}$ \\
\hline Credits \& Attributions & $\checkmark$ & $\checkmark$ & $\checkmark$ & $\checkmark$ \\
\hline Table of Contents & $\checkmark$ & $\checkmark$ & $\checkmark$ & $\checkmark$ \\
\hline Menu (Jump Page) & $\checkmark$ & $\checkmark$ & $\checkmark$ & $\checkmark$ \\
\hline Number of Modules & 3 & 2 & 2 & 2 \\
\hline Learning Objectives & $\checkmark$ & $\checkmark$ & $\checkmark$ & $\checkmark$ \\
\hline Module Navigation Tabs & $\checkmark$ & $\checkmark$ & $\checkmark$ & $\checkmark$ \\
\hline Next Button on Success & $\checkmark$ & $\checkmark$ & $\checkmark$ & $\checkmark$ \\
\hline Progress Counter & $\checkmark$ & $\checkmark$ & $\checkmark$ & $\checkmark$ \\
\hline Lesson Length & 66 Pages & 49 Pages & 28 Pages & 49 Pages \\
\hline $\begin{array}{c}\text { Learning Interactions \& } \\
\text { Static Resources }\end{array}$ & $\begin{array}{l}\text { DNA \& Protein } \\
\text { Synthesis lesson }\end{array}$ & $\begin{array}{l}\text { Segregation \& } \\
\text { Meiosis Lesson }\end{array}$ & $\begin{array}{c}\text { Independent } \\
\text { Assortment Lesson }\end{array}$ & $\begin{array}{c}\text { Pedigree Analysis } \\
\text { Lesson }\end{array}$ \\
\hline Static Info Pages (\%) & $14(21 \%)$ & $9(18 \%)$ & $5(18 \%)$ & $10(20 \%)$ \\
\hline Drag and Drop Activities & 6 & 6 & 1 & 2 \\
\hline Text Entry Box Activities & 9 & 22 & 28 & 42 \\
\hline Click Box Activities & 0 & 8 & 28 & 38 \\
\hline On-demand Popups ( $\%$ / Page) & $8(12 \%)$ & $4(8 \%)$ & $4(14 \%)$ & $9(18 \%)$ \\
\hline Rollover Help Info (\% / Page) & $0(0 \%)$ & $3(6 \%)$ & $3(11 \%)$ & $7(14 \%)$ \\
\hline Feedback ( $\%$ / activity Page) & $40(77 \%)$ & $41(103 \%)$ & $62(270 \%)$ & $99(254 \%)$ \\
\hline Drop Down Activities & 3 & 0 & 0 & 3 \\
\hline Embedded Videos & 5 & 3 & 2 & 3 \\
\hline Fill in the blank question & 0 & 1 & 0 & 0 \\
\hline Multiple Choice Questions & 12 & 11 & 4 & 7 \\
\hline Searchable Glossary & $x$ & $\checkmark$ & $\checkmark$ & $\checkmark$ \\
\hline Total Learning Activities & 43 & 59 & 71 & 109 \\
\hline
\end{tabular}

such as avatars, activity-related components and sound tracks (Jayalath \& Esichaikul, 2020). Each module was designed to be completed within approximately 20 minutes (i.e., the estimated average attention span of adult learners (Middendorf \& Kalish, 1996)). Drop-down table-of-contents and ubiquitous module tabs facilitated fine and gross lesson navigation, respectively by students. Lessons also contained a variety of leaning activities such as multiple-choice questions, drag-and-drop interactions, text entry boxes and drop-down selection activities. Non-assessable marks were associated with each lesson so that students could map their learning success (i.e., a 
decline in the number of off-campus students who accessed lessons 2 and 3 compared to lesson 1 to augment their study of genetics. Moreover, significantly $(\mathrm{p}<0.05)$ fewer on-campus students used the gamified genetics

Figure 2. An example of the genetics short answer question of the final invigilated exam.

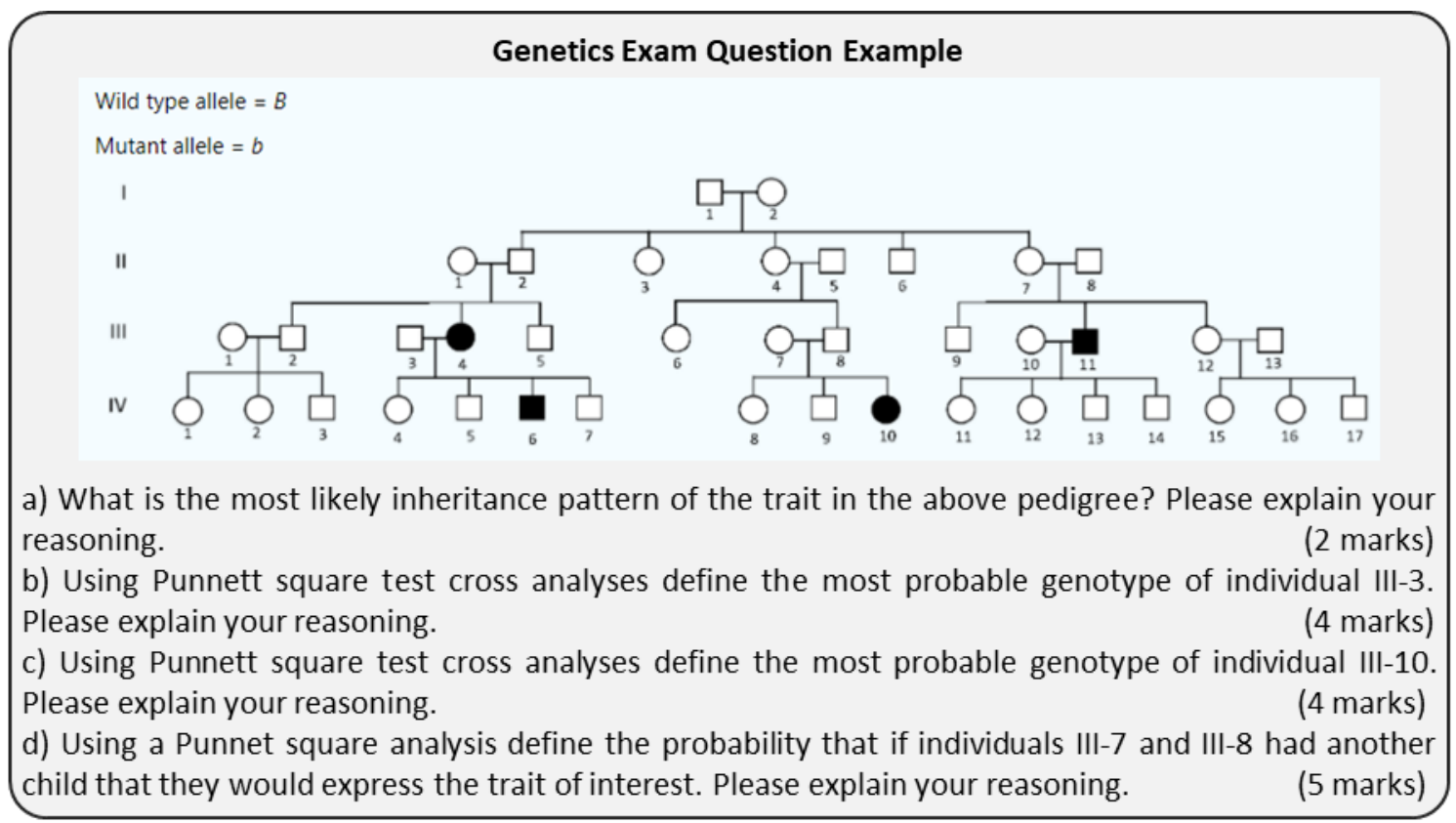

lessons to support their learning compared to the off-campus student usage of genetics lesson 1 . These data may indicate that there was online lesson fatigue demonstrated by students studying molecular genetics with blended teaching. Similarly, during 2020, when first year biology was delivered exclusively online, a small, but significantly $\left(\chi^{2}>11.806 ; p<0.0027\right)$ greater number of off-campus students used the first genetics lesson compared to those who used lessons 2 and 3. Some gamified lesson use fatigue trend was also apparent in the on-campus student cohort.

A

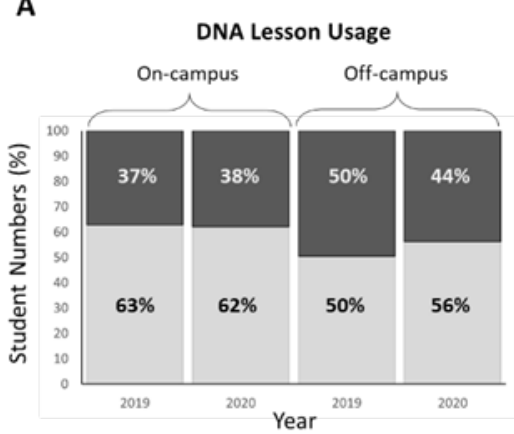

B

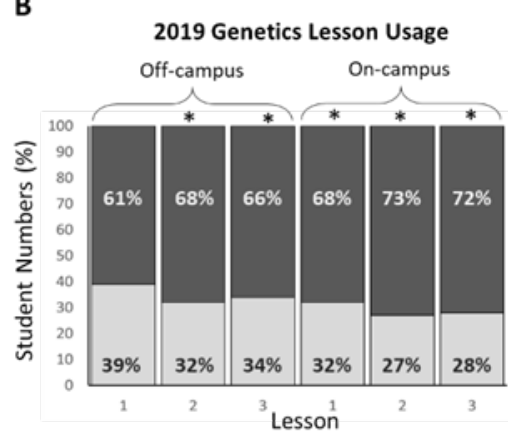

C

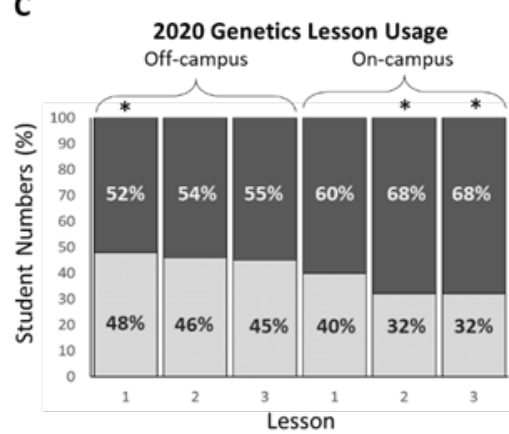

Figure 3. Student lesson usage data for 2019 and 2020 for first year biology. (A) The percentages of onand off-campus students that used the DNA lesson once $(\square$ ) or that did not use the DNA lesson ( $\square$ ) throughout the teaching periods in 2019 or 2020. (B) The percentages of on- and off-campus students that used all three genetics lessons once $(\square$ ) or students who did not use any of the genetics lessons ( $\square$ ) 2019 or (C) 2020 .

\section{Student learning outcomes associated with gamified lesson use.}

Not all students enrolled into the first-year biology course voluntarily accessed these gamified lessons to support their molecular genetics learning, Therefore, it was hypothesised that the student outcomes on the molecular genetics final exam questions would improve if they had used these lessons compared to students who chose not use these lessons. In 2019 (pre-COVID-19), when a blended delivery mode was used, both on- and off-campus students who used the online DNA lesson during the teaching period achieved a significantly $(p<0.004)$ higher 
average grade for the molecular biology question on their final invigilated exam compared to students who did not use the online DNA lesson (Figure 4). However, in 2020, during the COVID-19 lockdown, on-campus students who accessed the DNA lesson had a significantly $\left(\mathrm{p}=1.30 \times 10^{-6}\right)$ higher average grade on the final DNA exam question than students who did not use this lesson, whereas there was no difference in the average grade on the final molecular short answer exam question between students that did or did not use this lesson. The average grade achieved by the 2019 on-campus student cohort who used all three genetics lessons were significantly $(\mathrm{p}=0.0023)$ higher compared to on-campus students who chose not to use these lessons, whereas in 2020 there were no differences in these cohorts for the average grade achieved on the genetics short answer question for the final exam. Thus, the deployment of a single gamified lesson may have proven more effective at enhancing the learning outcome of students than the deployment of multiple lessons to teach a topic.

A

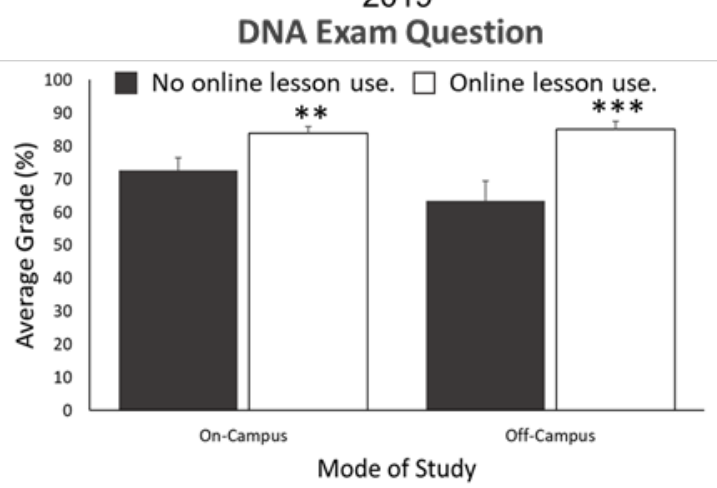

B

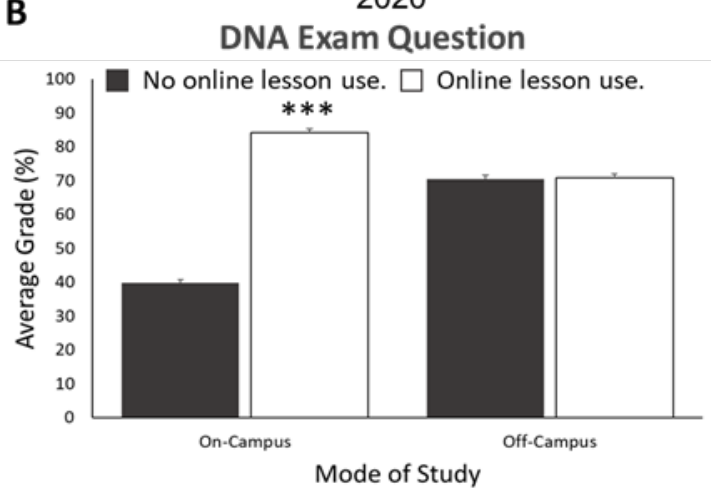

C

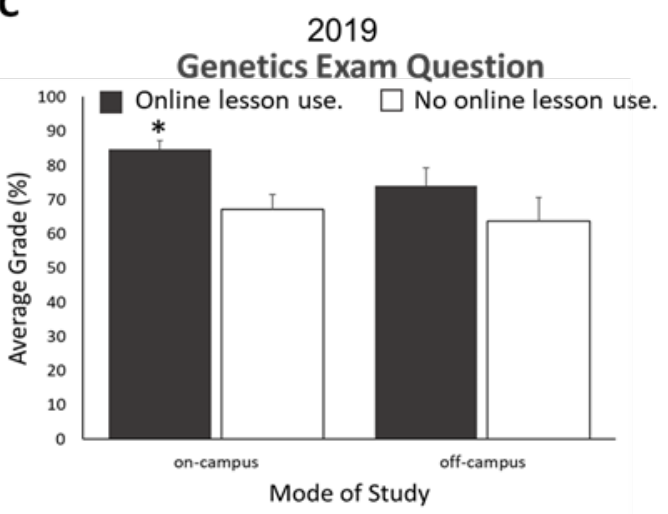

D

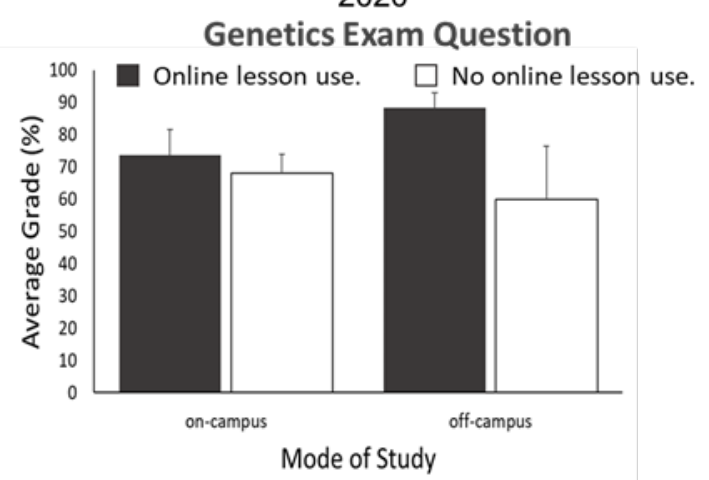

Figure 4. Average grades of on- and off-campus students who used or did not use the gamified lessons. (A and B) The percentage of average grades of on- and off-campus students who either used ( $\square$ ) or did not use ( $\square$ ) the online DNA lesson and who answered the molecular biology short answer question in the 2019 and 2020 invigilated final exams. (C and $D)$ The percentage of average grades of on- and off-campus students who either used $(\square)$ or did not use $(\square)$ all three genetics lessons and who answered the genetics short answer question in the 2019 and 2020 invigilated final exams. ${ }^{*} p<0.05 ; * * p<0.01, * * * p<1 \times 10^{-5}$.

In 2019 and 2020, 93\% and 77\%, respectively of on-campus student who accessed the DNA lesson once, passed the molecular biology exam question (Figure 5). Similarly, in 2019 and 2020, 93\% and 79\%, respectively of offcampus students who used the DNA lesson once, passed the molecular biology short answer question on the final exam. Thus, significantly more students who used the DNA lesson in 2019 (pre-COVID-19), blended delivery and 2020 (COVID-19) online only delivery modes passed the final molecular biology short answer exam questions. For the genetics section of the course, since three lessons were developed, the learning outcomes of only those students who used all three gamified lessons were considered in the analysis. In 2019 and $2020,96 \%$ and $72 \%$, respectively of on-campus students who used all of the genetics lessons at least once, passed the short answer genetics question on the final exam. Similarly, for both 2019 and 2020, 88\% of offcampus students who used these lessons passed the genetics short answer question on the final exam. Across all student cohorts and years, a minority of students who used these online lessons failed the molecular genetics short answer questions on the final exam with the exception of the 2020 molecular biology question. Thus, these data suggested that usage of the online gamified lessons by students to support their learning of molecular 
genetics was associated with successfully passing the short answer molecular genetics questions on the final invigilated exams, independent of the mode of delivery of the course material.

Since it was apparent that student engagement with the gamified lessons was associated with an increase in the pass rate for both on- and off-campus students independent of blended or exclusively online delivery, the effect of learning success was further quantified relative to grade stratifications achieved by students who used these gamified lessons compared to student who did not use these lessons (Figure 6). Stratification of grades from the

A

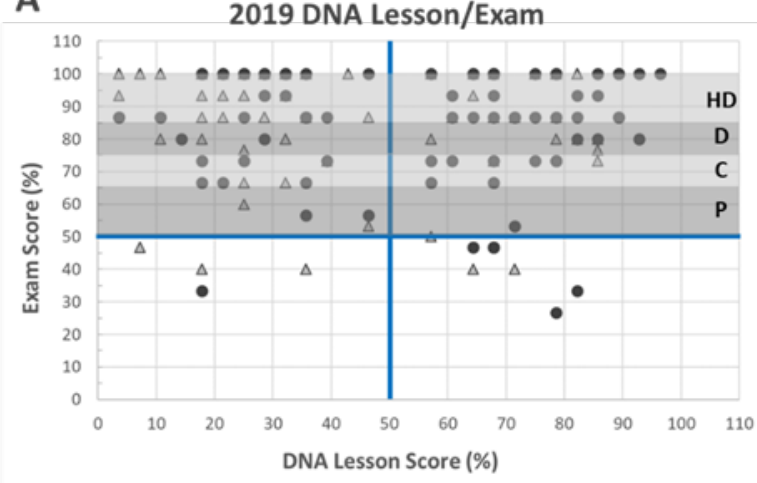

B

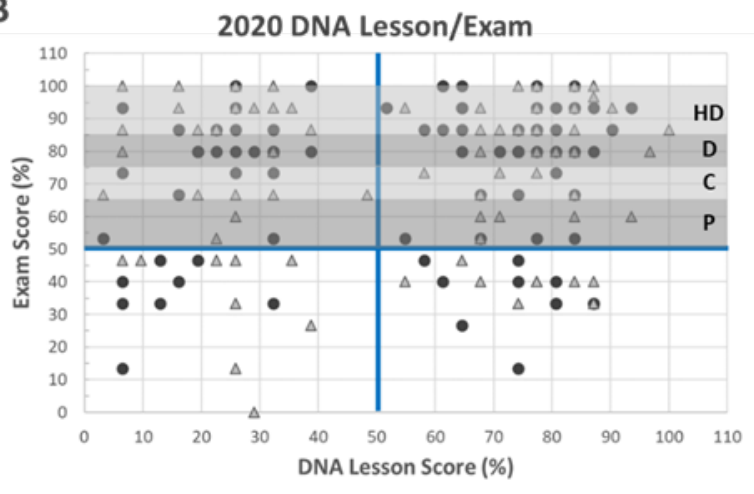

$\triangle$ Off-campus
C

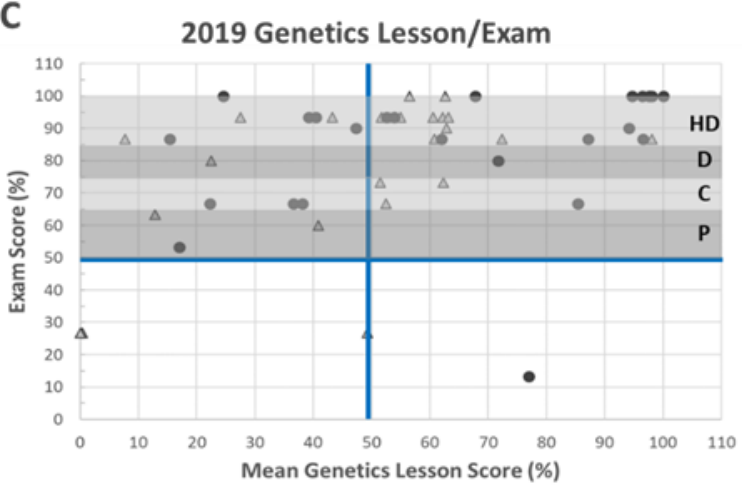

D

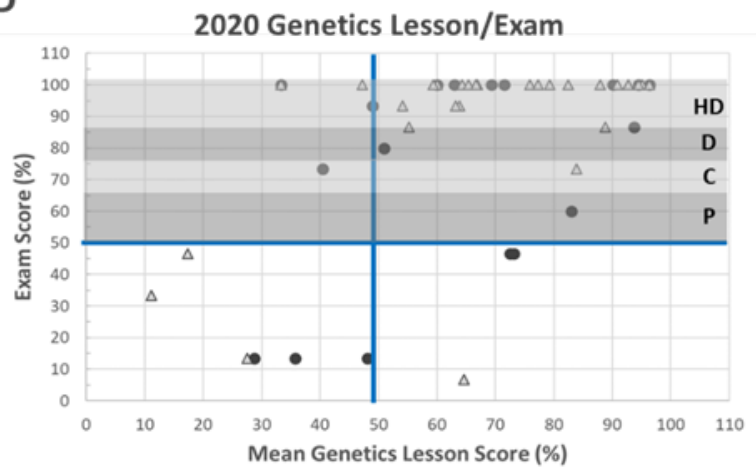

Figure 5. Quadrant plots demonstrating the molecular genetics short answer question exam scores against gamified lesson scores for $(A$ and $B)$ the DNA synthesis lesson and $(C$ and $D)$ the genetics lessons for on-campus $(O)$ and off-campus students $(\triangle)$. Note for the DNA lesson data is presented for students who used the lesson once, whereas for the genetics lessons data is presented for students who used all three lessons to augment their learning. High distinction (HD; 100-85\%), Distinction (D; 84-75\%), Credit (C; 74-65\%), Pass (P; 64-50\%) and Fail (F; 49-0\%).

molecular question on the 2019 invigilated final exam demonstrated that there were significant increases in the number of both on- $\left(\chi^{2}=8.455 ; p=0.0146\right)$ and off-campus $\left(\chi^{2}=11.268 ; p=0.0036\right)$ students that failed the molecular biology invigilated exam question and who did not access the online DNA lesson during the teaching period. Also, in 2019 there was a significant $(\mathrm{p}=0.0083)$ increase in the number of off-campus students who achieved a passing grade for the molecular biology short answer exam question who accessed the DNA lesson compared to students who did not use this lesson. Similarly, in $2020\left(\chi^{2}=9.9054 ; p=0.0071\right)$, significantly more on-campus students who did not use the gamified DNA lesson failed the molecular biology question on the final invigilated exam compared to students who used the lesson, whereas, there were no differences in grade stratification observed for the 2020 on- or off-campus cohorts. Similar trends were apparent for the students who answered the genetics short answer question on the final invigilated exams. Collectively, these exam data suggested that use of molecular genetics lessons by students was associated with better exam pass rates, but did not significantly improve the proportion of students achieving the higher grades on the molecular biology or genetics short answer questions in the final exam. 


\section{Discussion}

This study describes the development, deployment and student outcomes of gamified lessons designed to teach students foundational concepts in molecular biology and Mendelian genetics. These data supported the hypothesis that the use of gamified lessons by students, was associated with successful learning outcomes, as determined by

A

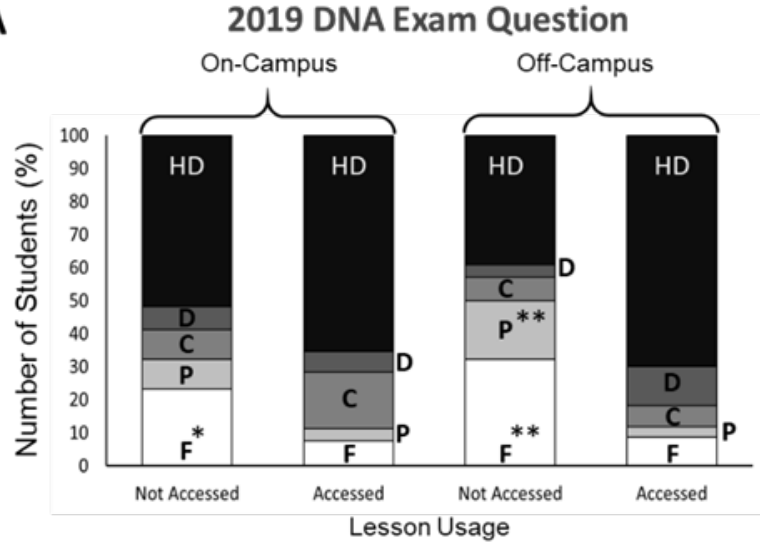

B

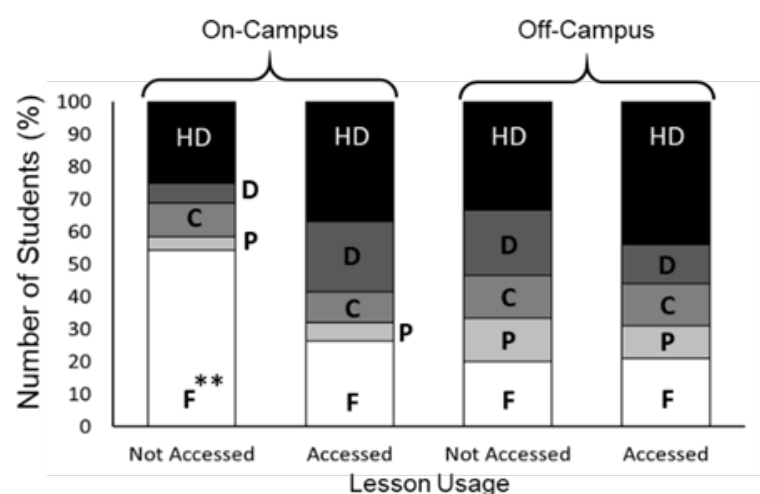

C

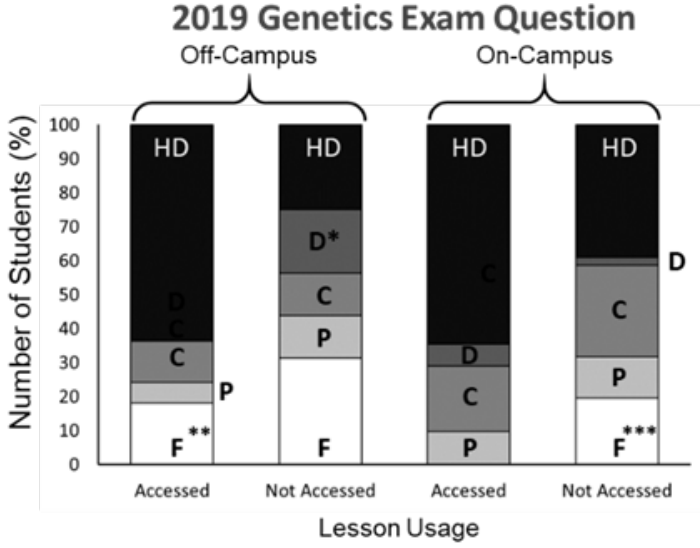

D

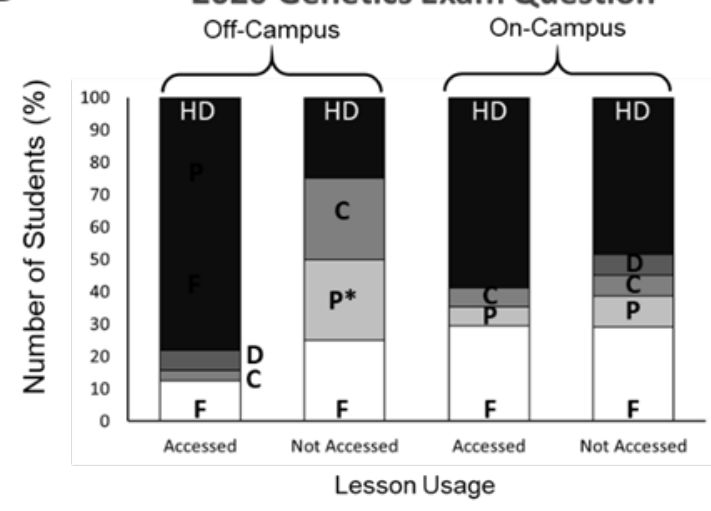

Figure 6. The grade distributions of on- and off-campus students who used the gamified lessons compared to students who did not use these lessons to support their learning. (A and C) Percentage grade distribution of on- and off-campus students who either used or did not use the online DNA lesson and who answered the molecular biology short answer question in the 2019 and 2020 invigilated final exams. (B and D) Percentage grade distribution of on- and off-campus students who either accessed or did not access all three genetics online lessons and who answered the genetics short answer question in the 2019 and 2020 invigilated final exams. High distinction ( $\square$; HD; 100-85\%), Distinction ( $\square$; D; 84-75\%), Credit $(\square ; \mathbf{C} ; 74-65 \%)$, Pass $(\square ; \mathbf{P} ; 64-50 \%)$ and Fail $(\square ; \mathrm{F} ; 49-0 \%) .{ }^{*} \mathbf{p}<0.05 ; * * p<0.01 ; * * * p<0.005$.

invigilated exam success, compared to students who did not use these lessons when studying molecular genetics via blended or online learning modes. Design of effective gamified lessons should contain intuitive but unobtrusive navigation features thereby allowing the student to concentrate on the lesson content game mechanics (Moshirnia \& Israel 2010), thus potentially enhancing their learning experience (Pilke, 2004). In these lessons, both coarse and fine navigation controls were included to facilitate maximum navigation flexibility, thereby enhancing the usability of these lessons for prima facie learning as well as revision by students. A gamification meta-analysis study of STEM subjects demonstrates that these types of resources significantly increased STEM student learning outcomes (Huang et.al., 2020). Pleasingly, this same metaanalysis study identified that the game components included in our lessons (Table 1) have benchmarked our gamified lessons at world's best practice, since these components are recognised as important game elements that facilitate STEM learnings by students.

Importantly, student progression through gamified lessons must be balanced against overloading students with too much information, which although essential for the learning outcomes of the lesson may impede students from completing these lessons. Features that enhance student progression, include the provision of immediate 
feedback (Alabbasi, 2018; Doney, 2019; Sepehr \& Head, 2013) and hints, designed to support informed student choices during their learning activities. These features also promoted increased concept comprehension (Kanthan \& Senger 2011). However, feedback considerations must be balanced against the temptation of designers to include too much information via the excessive use of pop-ups in gamified lessons, which detracts from lesson flow (Moshirnia \& Israel 2010). Thus, on-demand popups were included in these lessons to support student who desired extra support for their comprehension. The provision of on-demand pop-up access did not detract from lesson game flow and enabled students who did not desire this level of enhanced support to maintain their progression rate through the lesson. Similarly, a virtual tutor avatar was used to give feedback to students as well as provide them with on-demand hints to assist students with their learning, thereby minimising the use of informational popup windows in the lesson. Avatars also enhance the quality of learner engagement by guiding and retaining student attention without textual overload. However, student feedback indicated that excessive narration by the avatar was distracting, thus narration was strategic and terse.

A diversity of learning activities in gamified lessons is also recommended (Huang et.al., 2020, Bonora et al., 2019; Filippou et al., 2018) to achieve the learning objectives (Bicen \& Kocakoyun, 2018; Loos and Crosby, 2017; Meinel \& Schweiger, 2016) and is associated with improved student performance. Thus, the gamified molecular genetics lessons contained assorted learning activities which were expected to increase the recall of concepts by students (Fotaris et al., 2016) and improve student attention (Alabbasi, 2018).

The gamified lessons were deployed as a hub and spoke resource, designed to be the primary learning resources of the molecular genetics module in the first-year biology course. As the principal learning resources, the students were encouraged to supplement the gamified lessons with lectures delivered by the teaching staff. As such, these lessons were the centrepiece of the 2019 pre-COVID-19 blended delivery of the molecular genetics' module the biology 1 course. Most of the on- and off-campus students who used these lessons passed the corresponding short answer question in the final invigilated exam. Consequently, the use of these lessons by the students was associated with fewer failures suggesting these lessons may have augmented student comprehension of molecular genetics. This trend continued during the 2020 COVID-19 lockdown when the molecular genetics content was only delivered online, suggesting that using gamified molecular genetics lessons supported remote student learning.

However, if gamified lessons are used in isolation to promote deep understanding of highly conceptual topics by students there was no increase in the performance of students (Aji \& Napitupulu, 2018; Orhan et al., 2019). Therefore, teachers should provide direct learning support to students when using these types of lessons. For this reason, the molecular genetics lessons were deployed as the primary learning resources that were supplemented with additional learning material as required, and especially frequent teaching staff communications with students (Burns et al., 2021).

\section{Limitations, Conclusions and Recommendations}

A perceived limitation in the design of this study was the omission of student learning outcomes from mandatory student pre- and post-lesson testing metrics. However, by employing voluntary student lesson use as the independent variable, lesson use fatigue could be ascertained, which has curriculum design implications. In conclusion, when the gamified lessons were used by on- and off-campus students as part of their learning strategy, most students had successful learning outcomes in either blended or online only learning environments. In contrast, students who chose not to use these lessons had significantly greater failure rates for the molecular genetics short answer questions in the final invigilated exam. Recommendations from this study include:

- That the use of well-designed, gamified lessons, which teach foundational STEM concepts significantly enhanced student learning outcomes in blended and online-only learning environments, and that to develop these lessons, it would be advantageous for institutions to provide learning design support and/or academic teaching relief.

- Some gamified lesson fatigue was also observed and therefore, the overuse of these resources should be avoided and importantly, the gamified lessons did not replace lecturer-centred student support.

- Future research may include performance tracking students in scaffolded degrees where the concepts taught by gamified lessons in foundation courses are required knowledge for higher level course. 


\section{References}

Alabbasi, D. (2018). Exploring Teachers' Perspectives towards using gamification techniques in online learning. Turkish Online Journal of Educational Technology 17, 34-45. https://eric.ed.gov/?id=EJ1176165

Al-Azawi R., Al-Faliti, F. \& Al-Blushi, M. (2016). Educational gamification vs. game based learning: Comparative Study. International Journal of Innovative Management Technology 7, 132-36. https://doi.org/10.1007/978-3-319-76908-0 35

Aji, T.P. \& Napitupulu, T.A. (2018). Effect of gamification on E-learning to support learning achievement and learning motivation. Journal of Theoretical Applied Information Technology. 96, 3643-53. http://www.jatit.org/volumes/Vol96No12/4Vo196No12.pdf

Aldemir, T., Celik, B. \& Kaplan, G. (2018). A qualitative investigation of student perceptions of game elements in a gamified course. Computers in Human Behavior, 78, 235-54. 10.1016/j.chb.2017.10.001

Bai, S., Hew, K.F. \& Huang, B. (2020) Does gamification improve student learning outcome? Evidence from a Meta-Analysis and Synthesis of Qualitative Data in Educational Contexts. Education Res. Rev.30, 100322. 10.1016/j.edurev.2020.100322

Bevins K.L. \& Howard C.D., (2018). Game mechanics and why they are employed: What we know about gamification so far. Issues and Trends in Ed. Tech. $610.2458 / \mathrm{azu}$ itet v6i1 bevins

Bicen, H., \& Kocakoyun, S. (2018). Perceptions of Students for Gamification Approach: Kahoot as a Case Study. Int. J. Emerging Technology Learning. 13, 72-93. 10.3991/ijet.v13i02.7467

Boulton, CA, Kent, C \& Williams, HTP (2018) Virtual learning environment engagement and learning outcomes at a 'bricks-and-mortar' university. Computers \& Education. 126, 129-42. 10.1016/j.compedu.2018.06.031

Bonora, L., Martelli, F., \& Marchi, V. (2019). An amazing way to learn STEM concepts developing sustainable cities idea in the citizens of the future: the methodology of erasmus + project DIGITgame (digital improvement by game in smart city projecting). In Proceedings of the 10th International Conference on EEducation, E-Business, E-Management and E-Learning - IC4E'19 (pp. 18-22). New York, New York, USA: ACM Press. https://doi.org/10.1145/3306500.3306536

Briggs, A., Morgan, S., Sanderson, S., Schulting, M., \& Wieseman, L. (2016) Tracking the resolution of student misconceptions about the central dogma of molecular biology. Journal of Microbiology Biology Education. 17, 339-50. 10.1128/jmbe.v17i3.1165

Burns, A., Labeur, L., \& Andronicos, N. (2021) From blended to fully interactive online learning in foundation biology: lessons learnt during 2020. International Journal of Learning and Teaching (in press).

Cheesman, K., French, D., Cheesman, I., Swails, N., \& Thomas, J. (2007). Is there any common curriculum for undergraduate biology majors in the 21 st century? BioScience, 57, 516-522. 10.1641/b570609

Cobb, M. (2017) 60 years ago, Francis Crick changed the logic of biology. PLoS Biology. 15(9): e2003243. 10.1371/journal.pbio.2003243

Crick, F.H.C. (1958) On protein synthesis. Symptoms Sociology Expperiential Biology. 12:138-163. https://www.academia.edu/1022577/Crick_F._H._C. 1958 On_protein_synthesis

Crawford, J., Butler-Henderson, K., Rudolph, J., Malkawi, B., Glowatz, M., Burton, R., Magni, P., \& Lam, S. (2020) COVID-19: 20 countries' higher education intra-period digital pedagogy responses, Journal of Applications Learning \& Teaching, 3, 1-20. 10.37074/jalt.2020.3.1.7.

DeBruyn, J.M. 2012. Teaching the central dogma of molecular biology using jewellery. Journal of Microbiology Biology Education. 13, 62-64. 10.1128/jmbe.v13i1.356.

Deutch, C.E. (2018) Mendel or Molecules First: What is the best approach for teaching general genetics? American Biology Teacher, 80, 264-69. 10.1525/abt.2018.80.4.264

Dicheva, D., Dichev, C., Agre, G. \& Angelova, G. (2015) Gamification in Education: A Systematic Mapping Study. J. Education Technology \& Society, 18, 75-88 International Forum of Educational Technology \& Society. https://www.jstor.org/stable/10.2307/jeductechsoci.18.3.75

Doney, I. (2019). Research into effective gamification features to inform e-learning design. Res. Learning Tech, 27. 10.25304/rlt.v27.2093

Filippou, J., Cheong, C., \& Cheong, F. (2018). A Model to Investigate Preference for Use of Gamification in a Learning Activity. Australasian Journal of Information Systems, 22. 10.3127/ajis.v22i0.1397

Fotaris, P., Mastoras, T., Leinfellner, R., \& Rosunally, Y. (2016). Climbing Up the Leaderboard: An Empirical Study of Applying Gamification Techniques to a Computer Programming Class. The Electronic Journal of E-Learning, 14, 94-110. http://www.ejel.org/volume14/issue2/p94

Garrison, D.R. (2016). E-learning in the 21st Century: A Framework for Research and Practice, 3rd ed. London: Routledge/Falmer. 10.4324/9781315667263 
Hall K., Dunitz J., \& Shields P. (2014). Build-a-polypeptide: a hands-on worksheet to enhance student learning in an introductory biology course. J. Microbiol. Biol. Educ. 15:307-309. 10.1128/jmbe.v15i2.735

Hanus, M. D., \& Fox, J. (2015). Assessing the effects of gamification in the classroom: A longitudinal study on intrinsic motivation, social comparison, satisfaction, effort, and academic performance. Computers and Education, 80, 152-161. 10.1016/j.compedu.2014.08.019

Huang, R., Ritzhaupt, AD, Sommer, M. et al. (2020). The impact of gamification in educational settings on student learning outcomes: A meta-analysis. Edu. Tech. Res. Dev. 68, 1875-1901. 10.1007/s11423-02009807-Z

Jayalath, J., \& Esichaikul, V. (2020) Gamification to Enhance Motivation and Engagement in Blended eLearning for Technical and Vocational Education and Training. Technology, Knowledge and Learning. 10.1007/s10758-020-09466-2

Kalogiannakis M., Papadakis S., Zourmpakis A-I. Gamification in Science Education. A Systematic Review of the Literature. Education Sciences. 2021; 11(1):22. 10.3390/educsci11010022

Kanthan, R. \& Senger, J. L. (2011) The impact of specially designed digital games-based learning in undergraduate pathology and medical education. Archives of Pathology \& Laboratory Medicine 135, 135142. http://www.archivesofpathology.org/doi/pdf/10.1043/2009-0698-OAR1.1

Kapp, K. M., Blair, L., \& Mesch, R. (2013). The gamification of learning and instruction fieldbook: Theory into practice. New York, NY: John Wiley \& Sons pp 224-237.

Kim S., Song K., Lockee B., Burton J. (2018) What is Gamification in Learning and Education? In: Gamification in Learning and Education. Adv. Game-Based Learning. Springer, Cham. 10.1007/978-3319-47283-6 4

Liu, D.Y.T., \& Taylor, C.E. (2013) Engaging students in large lectures of introductory biology and molecular biology service courses using student response systems. Proceeds Australian Conference Science Mathematics Education. 154-62. https://www.academia.edu/4614453

Loganathan P., Talib C., Thoe N., Aliyu F \& Zawadski, R. (2019). Implementing Technology Infused Gamification in Science Classroom: A Systematic Review and Suggestions for Future Research. Learn. Sci. Math. 14, 60-73. http://recsam.edu.my/sub 1smjournal/images/docs/2019/2019 5 PL 6073 Final.pdf

Loos, L. A. \& Crosby, M. E. (2017). Gamification Methods in Higher Education. In Learning and Collaboration Technologies (pp. 474-86). 10.1007/978-3-319-58509-3 37

Marshall, P.A. (2017) A Hands-On Activity to Demonstrate the Central Dogma of Molecular Biology Via a Simulated VDJ Recombination Activity. Journal of Microbiology Biology Education. 18: 10.1128/imbe.v18i2.1277

McLean, J.L., \& Schuman, E. (2016). Using magnets and classroom flipping to promote student engagement and learning about protein translation in a large microbiology class. Journal of Microbiology Biology Education 17, 288-89. 10.1128/jmbe.v17i2.1048

Meinel, C. \& Schweiger, S. (2016). A Virtual Social Learner Community-Constitutive Element of MOOCs. Education Sciences, 6, 22. 10.3390/educsci6030022

Middendorf J, \& Kalish A. (1996). The "Change-Up" in lectures. Natl Teach Learn Forum. 5 1-7. https://tchsotl.sitehost.iu.edu/part3/Middendorf\%20\&\%20Kalish.pdf

Mincov Tenório, M., Fernandes Reinaldo, F.A., Góis, L.A., Lopes, R.P., \& Junior, G. dos S. (2017). Elements of Gamification in Virtual Learning Environments: A Systematic Review. In $20^{\text {th }}$ International Conference on Interactive Collaborative Learning (pp. 1812-822). https://revistaespacios.com/a20v41n11/a20v41n11p26.pdf

Moshirnia, A., \& Israel, M. (2010) The educational efficacy of distinct information delivery systems in modified video games. J. Int. Learn Res, 21, 383-340. https://www.researchgate.net/publication/277819894

Olsson, M., Mozelius, P, \& Collin, J. (2015). Visualisation and Gamification of e-Learning and Programming Education. Electr. Journal of E-Learning, 13, 441-54. https://eric.ed.gov/?id=EJ1087309

Orhan Göksün, D., \& Gürsoy, G. (2019). Comparing success and engagement in gamified learning experiences via Kahoot and Quizizz. Computers and Education. 135, 15-29. 10.1016/j.compedu.2019.02.015

Pelletreau, K.N., Andrews, T., Armstrong, N., Bedell, M.A., Dastoor, F., Dean, N., Erster, S., Fata-Hartly, C., Guild, N., Greig, H., Hall, D., Knight, J.K., Koslowsky, D., Lemons, P.P., Martin, J., McCourt, J., Merrill, J., Moscarella, R., Nehm, R., Northington, R., Olsen, B., Prevost, L., Stoltzfus, J., Urban-Lurain, M., and Smith, M.K. (2016) A clicker-based study that untangles student thinking about the processes in the central dogma. CourseSource. 3. 10.24918/cs.2016.15. 10.24918/cs.2016.15

Pilke, E.M. (2004). Flow experiences in information technology use. International Journal Human-Computer Studies. 3, 347-357. 10.1016/j.jijhcs.2004.01.004

Redfield, R.J. (2012) Why do we have to learn this stuff? - A New Genetics for 21st Century Students. PLoS Biology 10(7): e1001356. 10.1371/journal.pbio.1001356 
Sheely, S. (2006). Persistent technologies: Why can't we stop lecturing online. Paper presented at the Proceedings of the $23^{\text {rd }}$ Annual Ascilite Conference: Who's learning? Whose technology? University of Sydney, Sydney. https://ascilite.org/conferences/sydney06/proceeding/pdf_papers/p167.pdf

Sepehr, S., \& Head, M. (2013). Competition as an element of gamification for learning. In Proceedings of the First International Conference on Gameful Design, Research, and Applications - Gamification '13 (pp. 2 9). New York, New York, USA: ACM Press. 10.1145/2583008.2583009

White, N.R. (2006). Tertiary education in the Noughties: The student perspective. Higher Education, Research Development, 25, 231-246. 10.1080/07294360600792947

White, B.T., \& Bolker, E.D. (2008) Interactive computer simulations of genetics, biochemistry, and molecular biology. Biochemistry Molecular Biology Education 36, 77-84. 10.1002/bmb.20152

Wright, L.K., Fisk, J.N., Newman, D.L. (2014). DNA $\rightarrow$ RNA: what do students think the arrow means? CBE Life Science Education 13, 338-348. 10.1187/cbe.cbe-13-09-0188

Yung S, Primm T. (2015) Nucleotide manipulatives to illustrate the central dogma. J. Microbiological Biological Education. 16: 274-277. 10.1128/jmbe.v16i2.901

Andronicos, N.M., Barnett, T.J., Roberts, R.R., Chong, S., Labeur, L., Henderson, S.M., \& Burns, A. (2021).

Gamified lessons support molecular genetics education of first year biology students during COVID-19

lockdown. In Gregory, S., Warburton, S., \& Schier, M. (Eds.), Back to the Future - ASCILITE '21.

Proceedings ASCILITE 2021 in Armidale (pp. 246-256). https://doi.org/10.14742/ascilite2021.0137

Note: All published papers are refereed, having undergone a double-blind peer-review process.

The author(s) assign a Creative Commons by attribution licence enabling others to distribute, remix, tweak, and build upon their work, even commercially, as long as credit is given to the author(s) for the original creation.

(c) Andronicos, N.M., Barnett, T.J., Roberts, R.R., Chong, S., Labeur, L., Henderson, S.M., \& Burns, A.

Cerimagic, S., \& Wardak, D. 2021 